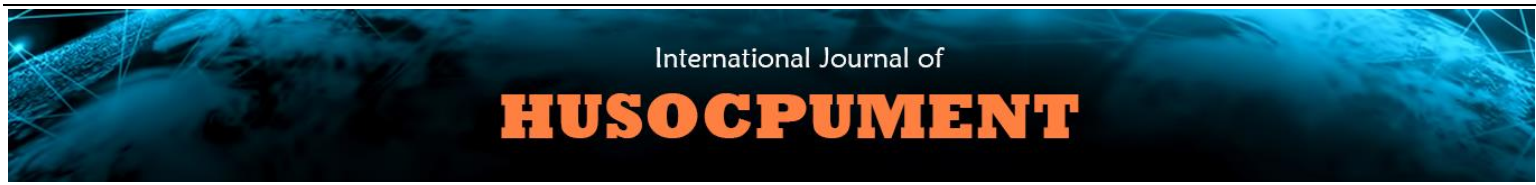

Journal of Humanities, Social Science, Public Administration and Management (HUSOCPUMENT)

Volume 1, Number 2, April 2021, pp. 77-84

https://www.publication.idsolutions.co.id/journals/index.php/husocpument/

DOI: https://doi.org/10.51715/husocpument.v1i2.60

\title{
Influence of Gender, Emotional and Spiritual Intelligence on the Level of Accounting Understanding
}

\author{
Ayu Indira Dewiningrat ${ }^{1}$, and Jonathan Jacob Paul Latupeirissa ${ }^{2}$ \\ ${ }^{1}$ Faculty of Economic and Business, Pendidikan Nasional University Denpasar, Bali \\ ${ }^{2}$ Faculty of Law and Social Sciences, Pendidikan Nasional University Denpasar, Bali \\ E-mail: ${ }^{1}$ dewiningrat@ undiknas.ac.id, ${ }^{2}$ jonathan.latupeirissa@undiknas.ac.id
}

Abstract-Understanding of accounting is someone who is clever and understands accounting properly. Accounting is a process of recording, classifying, summarizing, processing and presenting data, transactions and events related to finance so that it can be used by people who use it easily understood for making decisions and for other purposes. This study aims to determine the effect of gender, emotional intelligence and spiritual intelligence on the level of accounting understanding of students majoring in accounting at private universities in the city of Denpasar. Samples were taken by purposive sampling technique as many as 376 accounting students. The data analysis technique used is multiple linear regression analysis. The results of the analysis show that the gender variable affects the level of accounting understanding with a significance value of $0.000<0.05$, the emotional intelligence variable has no effect on the level of accounting understanding with a significance value of $0.74>0.05$, the spiritual intelligence variable has no effect on the level of understanding. Accounting with a significance value of $0.663>0.05$.

Keywords: Gender, Emotional Intelligence, Spiritual Intelligence

\section{Introduction}

In the world of education, there are many things that need to be considered to create quality students who can understand the lessons given by the lecturers, especially in terms of the teaching system delivered by the teacher in the room in the weight of the lessons delivered. However, a lack of concentration is needed and it affects the learning outcomes to be achieved. In lecturing activities, full concentration should be needed. However, in everyday life there are still many problems with the lack of concentration in student learning in class. Economic education, especially accounting, is the most popular department in both public and private universities. Great career opportunities will be obtained for graduates. The educational process developed by accounting education providers needs to be continuously modified and developed. It aims to produce graduates who are able to face change. Accounting education must produce professional accountants in line with the growing need for accounting services in the future. Accounting higher education that does not produce professionalism as an accountant will certainly not be accepted in the workforce (Wijayanti, 2015 ).

Competition in the world of work today is getting sharper due to the era of globalization. Rules in work are judged not only based on the level of intelligence, or based on training and experience, but also based on how well we manage ourselves and relate to others. Higher education in accounting as an institution that produces graduates in the field of accounting is currently required not only to produce graduates who master academic skills, but also have analytical techniques in the field of Humanistic Skills and Professional Skills so that they have additional value in competing in the world of work. Human quality itself is closely related to the quality of education, which is a series of primary, secondary and tertiary education. Education as an institution that equips students with reasoning and understanding of knowledge related to theory and its application in the world of practice. Learning is everyone's right, studying in a tertiary institution is a privilege because only people who meet the requirements have the right to study in that educational institution. Many students take the course pathway to get a bachelor's degree and in the end the bachelor's degree is used to fulfill one of the requirements to be able to work in a company. Many job seekers complain that many students have 
a high Cumulative Achievement Index (GPA) but lack personalities. One aspect of personality can be determined from his emotional intelligence (Wijayanti, 2015).

Students' emotional intelligence has an influence on student achievement. This emotional intelligence is able to train the ability to manage his feelings, the ability to motivate himself, the ability to be strong in the face of frustration, the ability to control impulses and delay momentary gratification, regulate a reactive mood, and be able to empathize and cooperate with others. This intelligence supports a student in achieving his goals and ideals. Intelligence includes the ability to read, write and count, which are words and numbers skills that are the focus of formal education (schools) and actually direct a person to achieve success in academia. But the definition of success in life is not only that. The new view that has developed says that there are other intelligences outside of intellectual intelligence (IQ) such as talent, social acuity, social relationships, emotional maturity and others that must be developed as well. The intelligence in question is emotional intelligence (EQ). Emotional intelligence was first posed in 1990 by psychologists named Peter Salovey of Harvard University and John Mayer of the US University of New Hampshire to describe emotional qualities that seem essential to success. Salovey and Mayer (1990) define emotional intelligence as the ability to recognize feelings, reach and evoke feelings to help thoughts, understand feelings and their meanings, and control feelings deeply so that they can help emotional and intellectual development (Rachmi, 2010). (Wijayanti, 2015). Emotional intelligence is the ability to feel, understand effectively. With these abilities students can recognize, control, motivate themselves and be able to empathize and socialize with the surrounding environment based on that ability itself to improve the quality of their understanding of accounting (Goleman, 2000),(Hariyoga and Supriyanto, 2011), (Wijayanti, 2015). According to research conducted by (Herlinda, 2015), (Sari, 2016), and (Somasari, 2017), it shows that emotional intelligence has a positive effect on accounting understanding, while (Wijayanti, 2015), (Ariasanti, 2016) state that emotional intelligence has no effect on accounting understanding.

Apart from emotional intelligence (EQ), spiritual intelligence (SQ) is one of the factors that can affect accounting understanding. Spiritual intelligence is a mind that gets inspiration, encouragement, inspired effectiveness, and a sense of divinity that all humans are part of (Sinetar, 2001), (Ariasanti, 2016). Spiritual intelligence is the intelligence to deal with and solve problems of the meaning of life, values, and self-integrity, namely intelligence to match our behavior and our lives in a broader and richer context of meaning, intelligence to judge that one's actions or way of life are more meaningful than those of others. other. One can find meaning in life from working, studying and asking questions. Even when faced with problems or suffering. Spiritual intelligence is the intelligence of the soul that helps heal and awaken the human self as a whole. Spiritual intelligence is the foundation necessary for the functioning of IQ and EQ effectively. In fact, SQ is the highest intelligence. Spiritual intelligence enables a person to recognize the value of attributes in others as well as in himself. A well-developed spiritual intelligence will be characterized by a person's ability to be flexible and easily adapt to the environment, to have a high level of awareness, to be able to deal with suffering and pain, to be able to take valuable lessons from failure, to be able to realize life in accordance with the vision and mission, being able to see the relationship between various things, being independent and ultimately making a person understand the meaning of his life (Zohar and Marshall, 2001), (Ariasanti, 2016). According to research conducted by (Dwijayanti, 2009), (Sumaryanto, 2013), (Sahara, 2014) shows that spiritual intelligence has no effect on accounting understanding, while (Herlinda, 2015), (Ariasanti, 2016), (Somasari, 2017) and (Fitriani, 2018) state Spiritual intelligence has a positive effect on accounting understanding.

Apart from emotional intelligence, spiritual intelligence as well as other factors that can affect understanding of accounting is gender. Nowadays, views on gender equality have increasingly eroded traditional opinions that regard men as superior to women (Suryawan, et al, 2021). The term gender was introduced by social scientists to describe the differences between men and women that are innate as God's creation and which are cultural forms that have been studied and socialized since childhood. In the context of gender differences related to academic achievement, it is an interesting content to study. Data from the Malaysian Ministry of Education (2000) regarding the judicial review decisions from 1996-1999 show that female students attained better academic performance than male students. Academic achievement achieved by a student is the result of interaction between various factors that influence it, both from inside and outside the student (Puspitawati, 2013), (Wijayanti, 2015), (Nanik Ariasanti, 2016). In the Women's Studies Encyclopedia it is explained that gender is a cultural concept that seeks to make a distinction in terms of roles, behaviors, catalyze, emotional characteristics between men and women that develop in society. A review from Sutherland and Australian statistics states that women's learning achievement is better than men's learning achievement. This is possible because female students learn and absorb the knowledge they get more often than male students (Tierney, 1989), (Tinklin, et al . 2000), (Wijayanti, 2015), (Fitriani, 2018). According to research conducted by (Wijayanti, 2015), (Ariasanti, 2016) shows that gender has no effect on accounting understanding, while 
(Fitriani, 2018) states that gender affects accounting understanding. The empirical evidence above can be seen, both from previous studies showing that there are differences in results that indicate influence and no effect in previous studies so that the authors are interested in investigating more deeply by taking the research location in Denpasar City.

\section{Literature Review and Hypothesis}

\section{A. Gender}

The term gender was introduced by social scientists to describe the differences between men and women that are innate as God's creation and which are cultural forms that have been studied and socialized since childhood. In Webster's New World Dictionary, gender is defined as the visible difference between men and women in terms of values and behavior. Gender is a trait inherent in both men and women that is socially and culturally constructed. The inherent nature can be exchanged, can be changed from time to time and from one place to another. At this time there is a tendency to increase the number of women choosing the profession in the accounting sector. The characteristics of women who are painstaking, meticulous, numeracy skills, memory and mental resistance to money and numbers, make them tend to prefer accounting (Ruditya, 2012), (Wijayanti, 2015), (Fitriani, 2018). A good understanding of accounting subjects will affect the ability of accounting students when they enter the world of work. The level of accounting understanding between one student and another student may differ. These differences can be related to a number of factors such as gender (Ruditya, 2012). Gender relations to accounting understanding. Gender is a trait inherent in both men and women that is constructed socially and culturally. In understanding accounting courses that are good will affect the ability of accounting students when they enter the world of work. The level of accounting understanding between one student and another student may differ. These differences can be related to a number of factors such as gender.

According to research by (Wijayanti, 2015), (Ariasanti, 2016) and (Fitriani, 2018), gender has a negative effect on accounting understanding, this shows that men and women have the same level of understanding of accounting. Men and women receive the same accounting course material from the lecturers of this course, while according to (Anantyo, 2014), gender has a positive effect on the level of accounting understanding. This can happen because women prefer to learn and absorb the knowledge they get than male students, which means that women's learning achievement is better than men's learning achievement. Based on this explanation, the hypotheses that can be proposed in this study are as follows:

\section{H1: Gender affects the level of understanding of accounting for student.}

\section{B. Emotional Intelligence}

Based on the traditional understanding, intelligence includes the ability to read, write and count, which are the skills of words and numbers that are the focus of formal education (schooling), and actually direct a person to achieve success in academia. But the definition of success in life is not just this. The new view that has developed says that there are other intelligences outside of intellectual intelligence (IQ), such as talent, social observation acuity, social relationships, emotional maturity, and others that must also be developed (Wijayanti, 2015), (Ariasanti, 2016). According to Salovey and Mayer, it is said that emotional intelligence is the ability to recognize feelings, reach and generate feelings to help thoughts, understand feelings and their meanings, and control feelings deeply so as to help emotional and intellectual development (Stein and Howard, 2002).

Emotional intelligence as the ability to know emotions effectively in order to achieve goals, and build productive and successful relationships. From, the meaning above emotional intelligence according to Patton is the ability to know emotions to achieve goals (Patton, 1998), (Wijayanti, 2015). Meanwhile, Bar-On (2000) argues that emotional intelligence is a series of emotions, emotional knowledge and abilities that affect the overall ability of individuals to deal with environmental demands effectively. This means that emotional intelligence is knowledge of emotions to solve problems. Another opinion expressed by (Goleman, 2000) emotional intelligence is the ability of a person to motivate himself, resilience in the face of failure, control emotions and delay satisfaction, and regulate the mental state (Wijayanti, 2015). From some of the opinions above, it can be concluded that emotional intelligence is an ability that a person has in recognizing one's own feelings and feelings of others and can control emotions in oneself and others. So that emotional intelligence here can help accounting students at private universities in Denpasar City to motivate themselves and manage emotions in learning to understand accounting. According to Goleman, he divides emotional intelligence into five parts, namely three 
components in the form of emotional competence (self-recognition, self-control and motivation) and two components in the form of social competence (empathy and social skills).

According to research conducted by (Sumaryanto, 2013), (Sahara, 2014) and (Ariasanti, 2016), it shows that emotional intelligence has a negative effect on the level of accounting understanding, due to the lack of awareness of students themselves prioritizing the main goal, namely learning to get good grades and responding to material. given in the class is less precise and effective. In other research conducted by (Dwijayanti, 2009), (Rachmi , 2010), (Suryanto, 2013), (Jayadi, 2013), (Suryaningsih, 2015) and (Wahyuni, 2016), the results show that emotional intelligence has a positive effect on the level of accounting understanding. Based on this explanation, the hypotheses that can be proposed in this study are as follows:

\section{H2: Emotional intelligence has a positive effect on the level of understanding of accounting for student.}

\section{Spiritual Intelligence}

According to Zohar and Marshall (2001), spiritual intelligence allows a person to recognize the value of traits in others as well as in himself. A well-developed spiritual intelligence will be characterized by a person's ability to be flexible and easily adapt to the environment, to have a high level of awareness, to be able to deal with suffering and pain, to be able to take valuable lessons from failure, to be able to realize life in accordance with the vision and mission, being able to see the connection between various things, independently and in the end making a person understand the meaning of his life.

According to Khavari (2000) in (Rachmi, 2010), spiritual intelligence is a faculty of the non-material dimension or the human soul. Spiritual intelligence as a diamond that has not been honed and is owned by humans. Humans must recognize as they are and then rub them so that they shine with great determination, use them towards wisdom, and to attain eternal happiness. According to (Sinetar, 2001), spiritual intelligence is a mind that gets inspiration, encouragement, inspired effectiveness, and a sense of divinity that all humans are part of. According to Wahab and Umiarso in (Panangian, 2012), spiritual intelligence is an intelligence that every human being is born with that makes humans live meaningful lives, always listen to the voice of their conscience, never feel in vain, everything they do is always valuable. From some of the opinions above, it can be concluded that spiritual intelligence is an attitude to recognize traits in oneself and in others to encourage and get inspiration in order to achieve lasting happiness. So that the spiritual intelligence in students can help accounting students at private universities in Denpasar to be motivated and concentrated to learn and understand accounting.

According to research by (Dwijayanti, 2009), (Sumaryanto, 2013) and (Sahara, 2014), it shows that spiritual intelligence has no effect on the level of accounting understanding because students are not open and cannot accept other people's opinions on their own shortcomings and weaknesses and these students do not have self-awareness through their abilities. to criticize yourself.

According to research conducted by (Rachmi, 2010), (Suryanto, 2013), (Wahyuni, 2015) and (Ariasanti, 2016), it shows that spiritual intelligence has a positive effect on the level of accounting understanding. This means that the better the application of spiritual intelligence, the understanding of accounting will increase. Awareness of students will be responsibilities greatly influence the understanding of accounting. Such as honesty in learning, behaving according to existing norms and values and accepting opinions from others for shortcomings and weaknesses. Based on this explanation, the hypotheses that can be proposed in this study are as follows:

\section{H3: Spiritual intelligence has a positive effect on the level of understanding of accounting for students.}

\section{Understanding of Accounting}

Understanding of accounting is someone who is clever and understands accounting properly. Accounting understanding will be measured using the value of accounting courses, namely introduction to accounting, intermediate financial accounting, and advanced financial accounting, auditing and accounting theory. Another opinion expressed by Sari on understanding of accounting is the process or way of accounting students in understanding accounting courses. Students can be said to master or understand accounting if the accounting knowledge they have acquired so far can be applied in their social life or in other words it can be practiced in the world of work (Sari, 2013). Basically, the concept of 
understanding accounting according to (Munawir, 2004) in (Sari et al . 2015) consists of three main parts, namely assets, debt and equity.

This research is intended to examine whether Gender, Emotional Intelligence, and Spiritual Intelligence against the Level of Accounting Understanding in Students of the Accounting Department of Private Universities in Denpasar City. These frameworks are presented in the form of a scheme or a chart showing the relationship of each variable and for the development of hypotheses, a framework of thinking can be seen in picture 1 as follows:

Picture 1

Conceptual Framework

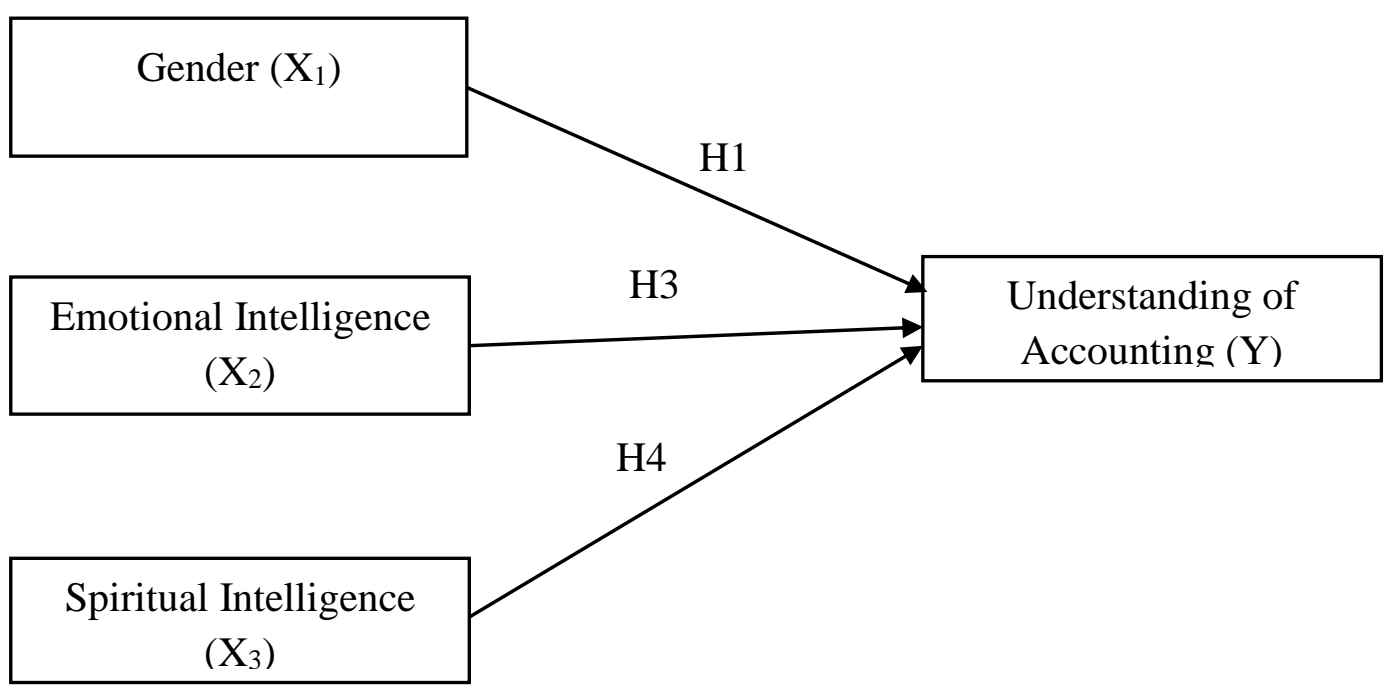

\section{Methods}

The research location is located in private universities in Denpasar City, including Mahasaraswati Denpasar University, Pendidikan Nasional University (Undiknas), Warmadewa University and Hindu Indonesia University (UNHI). This location was chosen because the researcher wanted to know the level of understanding of accounting courses among students majoring in accounting at the Private Higher Education in Denpasar City. In this study, the population will be Accounting Students at Private Universities in Denpasar City with a total of 4,638 accounting students. The sampling technique used in this study was purposive sampling technique to determine the sample with certain considerations in order to obtain samples that match the specified criteria. In this study, there are universities that are not allowed to search for student data and distribute questionnaires, namely the Pendidikan Nasional University because the student data from the university is confidential. In this study, there was also a university that could not be researched, namely the University of Hindu Indonesia because regular morning accounting students had already taken the free tuition system or were no longer effective in undergoing lectures and only focused on thesis preparation. So from private universities in Denpasar City who meet the criteria are regular class accounting students, namely Mahasaraswati Denpasar University and Warmadewa University. The data collection technique used in this research is by means of a questionnaire, which is a data collection technique that is done by giving a set of questions or written statements to the respondent to answer. To examine the effect of the independent variables (gender, emotional intelligence, and spiritual intelligence) on the dependent variable (Accounting Comprehension), this study uses multiple linear analysis with the equation of squares (ordinary least square OLS).

\section{Result and Discussion}

\section{A. Results of Multiple Linear Regression Analysis}


Multiple linear regression analysis is used to determine or obtain a description of the effect of independent variables on the dependent variable. The results of multiple linear regression analysis can be seen in table 1.

Table 1

Results of Multiple Linear Regression Analysis

Coefficients ${ }^{\mathrm{a}}$

\begin{tabular}{|c|c|c|c|c|c|c|}
\hline \multirow{2}{*}{\multicolumn{2}{|c|}{ Model }} & \multicolumn{2}{|c|}{$\begin{array}{l}\text { Unstandardized } \\
\text { Coefficients }\end{array}$} & \multirow{2}{*}{$\begin{array}{c}\begin{array}{c}\text { Standardized } \\
\text { Coefficients }\end{array} \\
\text { Beta }\end{array}$} & \multirow[b]{2}{*}{$t$} & \multirow[b]{2}{*}{ Sig. } \\
\hline & & B & Std. Error & & & \\
\hline 1 & (Constant) & 43.707 & 2.473 & & 17.674 & .000 \\
\hline & $\times 1$ & 1.373 & .326 & .281 & 4.212 & .000 \\
\hline & $\times 2$ & .074 & .041 & 118 & 1.796 & .074 \\
\hline & $\times 3$ & .018 & .041 & .028 & 437 & .663 \\
\hline
\end{tabular}

a. Dependent Variable: $Y$

Based on the table above, the multiple regression equation used in this study can be made as follows: $\mathrm{Y}=\mathrm{a}+\beta_{1} \mathrm{X}_{1}+\beta_{2} \mathrm{X}_{2}+\beta_{3} \mathrm{X}_{3}+\beta_{4} \mathrm{X}_{4}+\varepsilon$ $\mathrm{Y}=43.707+1.373 \mathrm{X}_{1}+0.257 \mathrm{X}_{2}+0.074 \mathrm{X}_{3}+0.018 \mathrm{X}_{4}$

The following is an explanation of the regression equation above:

1) The constant coefficient is 43.707 , this means that if the four independent variables are 0 (zero), then the understanding of accounting is 43.707 .

2) The value of the $\beta_{1}$ coefficient is 1.373 , this means that if each gender variable (x1) increases by 1 unit, the understanding of accounting will increase by 1.373 provided that gender $(\mathrm{x} 1)$, emotional intelligence (x2) and spiritual intelligence (x3) are constant or constant. . The results of the analysis show that the significance value of the gender variable is 0.000 , which is less than 0.05 , which means that gender has an effect on accounting understanding, thus the first hypothesis $\left(\mathrm{H}_{1}\right)$ is accepted.

3) The value of the $\beta_{3}$ coefficient is 0.074 , this means that if every 1 unit increase of emotional intelligence variable ( $\mathrm{x} 2)$, then the understanding of accounting will increase by 0.257 provided that, gender (x1), emotional intelligence (x2), spiritual intelligence (x3) ) constant or constant. The results of the analysis show that the significance value of the emotional intelligence variable is 0.074 , which is greater than 0.05 , which means that emotional intelligence has no effect on accounting understanding, thus the third hypothesis $\left(\mathrm{H}_{2}\right)$ is rejected.

4) The value of the $\beta_{4}$ coefficient is 0.018 , this means that if every 1 unit increase in the spiritual intelligence variable (x3), then the understanding of accounting will change by 0.257 provided that, gender (x1), emotional intelligence (x2), spiritual intelligence ( $\mathrm{x} 3$ ) constant or constant. The results of the analysis show that the significance value of the spiritual intelligence variable is 0.663 , which is greater than 0.05 , which means spiritual intelligence has no effect on accounting understanding, thus the fourth hypothesis $\left(\mathrm{H}_{3}\right)$ is rejected.

\section{B. Finding and Discussion}

Based on the first hypothesis which states that the gender variable affects the level of accounting understanding. This can be seen from the results of the $t$ test showing gender that the significance value of the gender variable is 0,000 , which is less than 0.05 , which means that gender has an effect on accounting understanding so that $\mathrm{H} 1$ is accepted. Gender is a trait inherent in both men and women that is socially and culturally constructed. The inherent nature can be exchanged, can be changed from time to time and from one place to another. At this time there is a tendency to increase the number of women choosing the profession in the accounting sector. The characteristics of women who are painstaking, meticulous, numeracy skills, memory and mental resistance to money and numbers, make them tend to prefer accounting (Ruditya, 2012), (Wijayanti, 2015), (Fitriani, 2018).

Academic achievement achieved by a student is the result of the interaction between various factors that influence it, both from inside and outside the student (Wijayanti, 2015). The results of this study indicate that women prefer to learn and absorb the knowledge they get than male students, which means that women's learning achievement is better than men's learning achievement. So that women's accounting understanding is better than men. The results of this study are consistent with the results of previous research by (Anantyo, 2014) which states that women's and men's accounting understanding is different.

Based on the second hypothesis which states that emotional intelligence has a positive effect on the level of accounting understanding. It can be seen in the results of the $t$ test that the significance value of 
the emotional intelligence variable is 0.74 , which is greater than 0.05 , which means that emotional intelligence has no effect on accounting understanding so that $\mathrm{H} 2$ is rejected.

Emotional intelligence is the ability to recognize your own feelings and feelings of others, motivate yourself, and manage emotions well in yourself and in relationships with others. High emotional intelligence can influence the behavior of others both positively and negatively. This is because having high emotional intelligence alone does not guarantee that a student will have the opportunity to learn emotional skills which are important for learning in order to get high achievement (Goleman, 2000). This shows that the lack of application of emotional intelligence will decrease students' understanding of accounting. Lack of awareness of the students themselves to prioritize the main goal, namely learning to get good grades and in responding to the material provided in class is less precise and effective. The results of this study are consistent with the results of previous studies by (Sumaryanto, 2013), (Sahara, 2014) and (Ariasanti, 2016) which show that emotional intelligence has no effect on the level of accounting understanding.

Based on the third hypothesis which states that spiritual intelligence has a positive effect on accounting understanding. This can be seen from the results of the $t$ test which states that the significance value of the spiritual intelligence variable is 0.663 , which is greater than 0.05 , which means that spiritual intelligence has no effect on accounting understanding so that H 3 is rejected. Spiritual intelligence does not have to be associated with one's closeness to the divine aspect (Rachmi, 2010). People who have high spiritual intelligence are able to give meaning to life by giving positive meanings to every event, problem, and even suffering they experience. Spiritual intelligence is intelligence to deal with problems of meaning or value, namely intelligence to place our behavior and life in a broader and richer context of meaning, intelligence to judge that one's actions or way of life are more meaningful than others (Zohar and Marshall, 2001).

This is because students are not open and cannot accept other people's opinions on their own shortcomings and weaknesses and these students do not have self-awareness through the ability to criticize themselves. Because many of the students have not been able to recognize themselves, which ultimately affects accounting learning, such as no honesty in learning, not behaving according to norms , and unable to accept opinions from others on their own shortcomings and weaknesses. The results of this study are consistent with previous research by (Dwijayanti, 2009), (Sumaryanto, 2013) and (Sahara, 2014) which states that spiritual intelligence has no effect on accounting understanding.

\section{Conclusion}

From the data obtained, the data analysis and discussion of the results of this study on the effects of gender, emotional intelligence and spiritual intelligence to the level of understanding of accounting, it can be formulated some of the conclusions $\mathrm{p}$ enelitian namely Gender effect on the level of understanding of accounting to students majoring in accounting College High Private universities in Denpasar City, emotional intelligence has no effect on the level of accounting understanding of students majoring in accounting at private universities in Denpasar City and spiritual intelligence has no effect on the level of understanding of accounting for accounting students majoring in private universities in Denpasar. This study is inseparable from various limitations so that it is hoped that these limitations can be refined in future studies. The limitation of this study is the possibility of bias towards the respondent's response due to the lack of seriousness of the respondent in providing answers to the questions from the questionnaire, causing the variables to be imperfectly measured. For further research it is expected that further research can add independent variables or intervening variables that can affect accounting understanding, because it does not rule out that research that includes more variables will be able to produce better conclusions. For example using learning environment variables, intellectual intelligence, social intelligence, and self-control . Further research is expected to expand the research location or population. For example, private universities throughout Denpasar and universities throughout Bali. The next researcher is advised to use the interview method or direct observation to the respondent, so that the respondent's answer can be controlled to avoid bias or misperception of the respondent on the question instrument used in the study.

\section{References}

[1] Anantyo, C. G. (2014). Pengaruh Kecerdasan Emosional, Kecerdasan Spiritual, dan Perilaku Belajar Terhadap Tingkat Pemahaman Akuntansi Berdasarkan Jenis Kelamin (Studi Empiris Pada Mahasiswa Tahun Angkatan 2012-2013 Jurusan Akuntansi Fakultas Ekonomi Universitas Jember). 
[2] Dwijayanti, Pengestu, A. (2009). Pengaruh Kecerdasan Emosional, Kecerdasan Intelektual, Kecerdasan Spiritual, dan kecerdasan Sosial terhadap pemahaman akuntansi.Jakarta. Jurnal. Universitas Pembangunan Nasional "Veteran".

[3] Ghozali, Imam.2016. Aplikasi Analisis Multivarite dengan Program IBMSPSS 23. Edisi Kedelapan. Semarang: Badan Penerbit Universitas Diponegoro.

[4] Goleman, D. (2000). Kecerdasan emosional. Gramedia Pustaka Utama.

[5] Hariyoga, S, dan Suprianto, E. (2011). Pengaruh Kecerdasan emosional, perilaku belajar, dan budaya terhadap tingkat pemahaman akuntansi dengan kepercayaan diri sebagai variabel pemoderasi. Simposium Nasional Akuntansi XIV.

[6] Herlinda, M. V. S. Pengaruh Kecerdasan Emosional, Kecerdasan Spiritual, Kecerdasan Sosial Dan Perilaku Belajar Terhadap Tingkat Pemahaman Akuntansi (Studi Empiris Mahasiswa Fakultas Ekonomi Jurusan Akuntansi Angkatan Tahun 2011 Universitas Jember). Jurnal Ilmiah Akuntansi Universitas Jember.

[7] Jayadi, A. R., \& Purwanti, L. (2013). Pengaruh Kecerdasan Emosional dan Perilaku Belajar terhadap Pemahaman Akuntansi (Studi Pada Mahasiswa Akuntansi Program S1 Universitas Brawijaya). Jurnal Ilmiah Akuntansi Universitas Brawijaya.

[8] Nanik Ariasanti, I Dewa Ayu. 2016. Pengaruh Kecerdasan Intelektual, Kecerdasan Emosional, Kecerdasan Spiritual, Perilaku Belajar, dan Gender terhadapa Pemahaman Akuntansi (Studi Kasus Pada Mahasiswa S1 Akuntansi Universitas Mahasaraswati Denpasar). Skripsi. Universitas Mahasaraswati Denpasar.

[9] Panangian, R. (2012). Pengaruh Kecerdasan Emosional dan Kecerdasan Spiritual Terhadap Pemahaman Akuntansi Pada Pendidikan Akuntansi. Jurnal Ilmiah Sekolah Tinggi Ilmu Ekonomi Perbanas.

[10] Patton, P. (1998). Kecerdasan Emosional di Tempat Kerja. Alih Bahasa: Zaini Dahlan, Pustaka Delaprata, Jakarta.

[11] Puspitawati, H. (2013). Konsep, teori dan analisis gender. Bogor: Departe-Men Ilmu Keluarga Dan KonSumen Fakultas Ekologi Manusia Institut Pertanian.

[12] Rachmi, Filia. 2010. Pengaruh Kecerdasan Emosional, Kecerdasan Spiritual, dan Perilaku Belajar Terhadap Pemahaman Akuntansi. Semarang. Jurnal Pendidikan Akuntansi.

[13] Ruditya, B. (2012). Perbedaan Tingkat Pemahaman Akuntansi Mahasiswa Berdasarkan Jenis Kelamin, Jurusan Saat SMA dan Angkatan Masuk Kuliah (Doctoral dissertation, Program Studi Akuntansi FEBUKSW). Jurnal Akuntansi Universitas Kristen Satya Wacana.

[14] Sahara, M. A. (2014). Pengaruh Perilaku Belajar, Kecerdasan Emosional, Kecerdasan Intelektual, Kecerdasan Spiritual, Dan Kecerdasan Sosial Terhadap Pemahaman Akuntansi (Universitas Maritim Raja Ali Haji). Jurnal Online Universitas Maritim Raja Ali, 1-23.

[15] Sari, I. P. (2016). Pengaruh Kecerdasan Emosional Terhadap Tingkat Pemahaman Akuntansi Pada Mahasiswa Jurusan Akuntansi (Survey di Perguruan Tinggi Wilayah Surakarta) (Doctoral dissertation, Universitas Muhammadiyah Surakarta). Jurnal. Universitas Muhammadiyah Surakarta

[16] Sari, N. P. K. M., \& Mendra, N. P. Y. (2015). Pengaruh Kecerdasan Emosional Dan Perilaku Belajar Terhadap Tingkat Pemahaman Akuntansi Pada Mahasiswa Akuntansi Unmas Denpasar. Skripsi. Universitas Mahasaraswati Denpasar.

[17] Sinetar, M. (2001). Spiritual Intelligence Kecerdasan Spiritual. Alih Bahasa Susanto Boddhi Dharmo, Jakarta: Alex Media Komputindo.

[18] Stein, S., \& Howard, E. (2002). The Eq Edge: Emotional Intelligence and Your Success Ledakan EQ: 15 Prinsip Dasar Kecerdasan Emosional Meraih Sukses. Murtanto terj. TRJ dan Y, editor. Bandung: Kaifa.

[19] Utami, M. T., \& Sumaryanto, S. (2013). Pengaruh Kecerdasan Emosional, Kecerdasan Spiritual, Perilaku Belajar, Dan Lingkungan Belajar Terhadap Tingkat Pemahaman Akuntansi Dengan Perkembangan Teknologi Sebagai Variabel Pemoderasi. Jurnal Reksa, 2(2), 139-157. 
[20] Wijayanti, Enik Dwi. (2015). Pengaruh Gender, Perilaku Belajar dan Kecerdasan Emosional terhadap Pemahaman Dasar Akuntansi dengan sampel mahasiswa Fakultas Ekonomi Program Studi Akuntansi angkatan 2013. Skripsi. Universitas Mahasaraswati Denpasar.

[21] Suryawan, I. M. Y., Ratnawati, N. L. T. T., \& Latupeirissa, J. J. P. (2021). The Conflict Analysis of Balinese Women on Equality in Work, Family and Social Life. Journal of Humanities, Social Science, Public Administration and Management (HUSOCPUMENT), 1(1), 26-31.

[22] Zohar, D., \& Marshall, I. (2007). SQ-Kecerdasan Spiritual. Mizan Pustaka. 